\title{
How to Improve the Financial Conditions of Local Governments in a Period of Crisis: An Explanatory Case Study
}

\author{
Giovanna Lucianelli ${ }^{1}$, Francesca Citro ${ }^{2}$, Serena Santis ${ }^{2}$, Alfredo Ettore Tranfaglia ${ }^{3} \&$ Andrea Mazzillo $^{1}$ \\ ${ }^{1}$ Department of Management and Law, University of Rome "Tor Vergata”, Rome, Italy \\ ${ }^{2}$ Department of Management and Information Systems, University of Salerno, Salerno, Italy \\ ${ }^{3}$ Department of Management and Law, University of Siena, Siena, Italy \\ Correspondence: Francesca Citro, Department of Management and Innovation Systems, University of Salerno, \\ Via Giovanni Paolo II, 132, 84084, Fisciano (SA), Italy. Tel: 0039-089-963-029. E-mail: fcitro@unisa.it
}

Received: November 9, 2017

Accepted: November 30, 2017

Online Published: December 20, 2017

doi:10.5539/ijbm.v13n1p53

URL: https://doi.org/10.5539/ijbm.v13n1p53

\begin{abstract}
The context of austerity and crisis in the local governments has focused on looking for a solution to avoid the distress while also improving financial health. Therefore, a system to monitor the financial situation of local authorities is needed in order to understand what the governments' proceeding to manage the crisis are. This paper aims to analyse the financial distress in the municipality of Rome to evaluate the processes that occur inside the "black box" of the organizational, institutional and strategic implementation of the reorganization practices and routines, also highlighting what are the indicators of the financial conditions that fall into either a positive or negative area so as to implement adequate planning. The analysis is conducted through an explanatory case study to understand and to explain the reasons for management practices in a condition of financial distress. The main finding shows that the case of Rome represents a good example of the financial resilience through a combination of capacities and reactions such as management of slack resources and income generation.
\end{abstract}

Keywords: financial distress, financial condition, explanatory case study, resilience

\section{Introduction}

In the last years, many countries have been effected by financial crisis both at central and local level. The main consequence was the inability to provide services at pre-existing levels along with the inability of a government to balance its budget (Pagano \& Moore, pp. 23).

In specific terms, the financial crisis can have an impact on different variables: revenues, either generated by local governments or derived from State transfers, which may be subject to sharp declines; expenditures, which are rising due to the slowdown in economic activity and the corresponding increases in unemployment and social welfare needs; financing capacities, which are decreasing due to the difficulty to obtain loans, along with an increase in the cost of debt (Paulais, 2009). Therefore, it became necessary to control the health conditions of local governments in order to avoid the distress. The attention towards the health conditions has been investigated for a relatively long time, the Governmental Accounting Standards Board (GASB, 1987) prescribes the rules to pursue, defining that a local government is in good financial condition if it is able to provide public services without damaging its ability to face future obligations. On the contrary, local governments in poor financial health are unable to deal with their financial obligations and still provide public services, resulting in the quality/quantity of these services often becoming damaged (Raphael, Renwick, Brown, \& Rootman, 2010).

Nowadays, the increasing decentralization in decision-making from central to local governments and in general, the context of austerity and crisis has focused on looking for a solution to avoid the distress while improving its financial health (Barbera, Jones, Korac, Saliterer, \& Steccolini, 2017).

One of possible solutions is resilience (National Audit Office, 2013; CIPFA, 2014). Resilience is the capacity for reaction to crises, expressed as passive resilience that is coming back to an original state; or active resilience that is the capacity to anticipate and cope with the unexpected through the development of new capabilities and the creation of new opportunities (Steccolini, Barbera, \& Jones, 2015). 
Accordingly, it could be of interest for both policy-makers and researchers to investigate the latter, focusing on the strategy a local government could implement in order to resolve the financial distress as well as improve its financial condition. Therefore, the definition and measurement of financial condition represents an early step to analysing the health condition of a local government.

The level of financial condition is not easy to represent, since it cannot be readily measured with a single performance indicator, but rather is determined by different measures and indicators, which are directly observable. Accordingly, current literature (Groves, Godsey, \& Shulman, 1981; Hendrich, 2004; Cabaleiro, Buch, \& Vaamonde 2012; Cuadrado Ballesteros, Mordán, \& García-Sánchez, 2014) has investigated the determinants of financial health in order to measure the financial condition; Groves et al. (1981) has proposed four types of indicators: cash solvency, budgetary solvency, long-run solvency and service-level solvency. Others authors (Greenberg \& Hiller, 1995; Zafra-Gómez, López-Hernández, \& Hernández-Bastida, 2006) and the CICA (1997) have proposed three indicators for measuring financial conditions: the level of sustainability, flexibility and vulnerability, in order to represent the ability of an entity to preserve the social welfare of citizens with the available resources.

This paper aims to analyse the financial distress in the municipality of Rome in order to understand the processes that occur inside the "black box" of the organizational, institutional and strategic implementation of the reorganization practices and routines (Parker, 2014), also highlighting what are the indicators of the financial conditions that fall into either a positive or negative area so to implement adequate planning. The study analyses if there is a combination of capacities and reactions such as management of slack resources or income generation, in order to define the financial resilience (Barbera et. al., 2017).

The analysis is conducted through an explanatory case study in order to understand and to explain the reasons (Scapens, 1990) for management practices in a condition of financial distress. The methodology provides four steps: (i) preparation (looking for information); (ii) collecting and assessing evidence (collecting financial reports); (iii) identifying and explaining patterns (themes and patterns have emerged with the link the various themes and issues); (iv) report and conclusions.

The main finding shows that the case of Rome represents a good example to follow, with the implemented strategies on the financial sustainability having led to positive effects. In the recent past, the municipality has had deal with several issues and notwithstanding it was in able to satisfy and pursuing some indicators of financial condition. This case study pursues the financial resilience through the combination of capacities and reactions such as management of slack resources and income generation (Barbera et. al., 2017).

The remaining parts of the paper are structured as follows. The next section highlights some of the key theoretical and practical elements about financial distress and conditions in local governments by referring in particular to some measures of budgetary solvency (such as sustainability, flexibility and vulnerability indicators), while the third section sets the context. After illustrating the case study methodology in the fourth section, section five investigates the case of Rome, the largest Italian municipality, which is experiencing a situation of crisis and where a plan to restore an improved financial condition is going to be implemented. The final section highlights a number of considerations on this topic as well as several conclusions and indications for future developments.

\section{Financial Distress and Financial Condition in A Local Government: A Framework}

\subsection{A Focus on the Financial Distress}

On the international scenario, local governmental distress is investigated by referring to: (i) the inability to provide services at pre-existing levels to citizens, essentially referring to the provision of the local infrastructure (Jones \& Walker, 2007); (ii) the effects on the financial distress of structural or fixed factors (such as the size of the local authorities, resident socioeconomic status and government resource allocation); organizational factors (such as performance evaluation, transparency and the role of the local government's management), and the hybrid factors (such as the relationship between the central and local governments) (Carmeli, 2008). However, it is worth noting that some factors are under the control of managers (as well as politicians) of a local government, while others are not (Bisogno, Citro, \& Tommasetti, 2014).

Besides, the literature (Park, 2004, Capalbo \& Grossi, 2014) has investigated what are the causes leading financial distress and two types have been identified: internal and external causes. Internal fiscal mismanagement, political mismanagement, internal lack of structural leadership and culture of inefficiency define the internal causes, while demographic changes, structural recessions, tax revolt, structural service demand, political pressure from creditors, interest group demand, judgment awards, and abrupt economic changes define the external 
causes.

Therefore, it is possible determine two approaches according the different causes: the social economic decline approach and the local management approach. The social economic decline approach assumes that the causes of financial distress are external to the local authorities and are beyond the control of local government officials (e.g. contraction of economic growth, movement of city dwellers to outskirts of the major cities, demographic changes such as increase in population, reduction in local business activity, unemployment and tax base erosion, bureaucracy and poor legislation). On the contrary, the local management approach identifies the real explicators of financial decline within the internal local management and political environment (e.g. incorrect managerial practices such as poor accounting and budgeting methods, incompetence and corruption among local officials, division of local governments in terms of political size and procedures as well as vulnerability of special interest groups). In conclusion, it is argued that financial distress is due to a combination of both external and internal factors (Capalbo \& Grossi 2014).

Regarding the measurement of financial distress, the use of the model capable of predicting it are used primarily in the private sector (Cohen, Doumpos, Neofytou, \& Zopounidis, 2012). In the public sector, only some countries (USA and Spain), use some systems or models to predict and identify the financial crisis (Kloha, 2005a, 2005b; Coe, 2008; Zafra-Gómez, López-Hernández, \& Hernández-Bastida 2009). However, in most of the cases, distress is calculated with the financial performance primarily assessed through the concept of financial condition (Carmeli 2003; Carmeli 2008; Honadle 2003; Dollery, Crase \& Byrnes, 2006; Audit Commission, 2007; Zafra-Gómez et al., 2009). Therefore, the measurement of financial condition is an indispensable way of evaluating the health status of local governments, considering that good financial health represents a prerequisite for convergence towards the objectives of any institution (Cabaleiro et al., 2013).

\subsection{A Focus on the Financial Condition}

The financial conditions of a public-sector entity focus on the availability of the resources required to maintain and/or improve the services provided to the citizens (Kloha 2005; Audit Commission 2007; Coe 2008); moreover, in order to define the financial condition of a public sector entity, the environmental factors also need to be taken into account. It is worth considering that the environmental factors determine society's needs and preferences, the local conditions that have an impact on the provision of public services, the cost of the productive factors, the resources available to society and the public policies affecting the local authority. Therefore, the services provided by a public sector entity depend on the necessities and socioeconomic characteristics of the population, which in turn provide resources, affecting the financial condition of the entity itself (Petersen 1977; Berne \& Schramm 1986; Berne 1992; Boyne 1996).

Subsequently, a public organization is in a good financial condition when it meets its debts and in turn provides acceptable levels of services. This means that the financial conditions of a public sector organization should be expressed through a set of well-known indicators regarding (Greenberg \& Hiller 1995; CICA 1997; Nollenberger, Groves \& Valente 2003):

- Short-term solvency (e.g. cash solvency), which refers to the relationships between cash inflows and outflows, expressing the ability of a public sector organization to generate enough liquidity to pay its short-term debts;

- Budget solvency, which refers to the ability of a public sector organization to raise sufficient revenues to cover its legally required expenditures without entering into deficit (Inman, 1995);

- Long-term solvency, which refers to the ability of public sector organizations to respond in an adequate manner to all its long-term obligations;

- Service-level solvency, which refers to the ability to provide and sustain essential services that stakeholders require and desire (e.g. citizens or students in the case of a public university).

In addition, several authors (Greenberg \& Hiller, 1995; Zafra-Gómez et al., 2006) along with the CICA (1997; 2009) have proposed three indicators to measure budgetary solvency:

- The level of sustainability, such as the ability of an entity to promote and preserve the social wellbeing of the citizens through public policies and public services delivery - e.g. it is the ability to maintain the existing public services and cover obligations to creditors without increasing indebtedness and taxation levels (Cuadrado-Ballesteros, Mardàn, \& Frías-Aceituno, 2016);

- The level of flexibility, such as the capacity of an entity to respond to changes in the economy or in its financial circumstances, within the limits of its fiscal abilities via modifications to tax rates, public debt or 
transfers;

- The level of vulnerability, such as the level of dependence of an entity in relation to external financing received via transfers and grants.

Table 1 summarizes several indicators which are generally used by scholars as a proxy of the financial health in LGs (Lopez-Hernández, Zafra-Gómez, \& Ortíz-Rodríguez, 2012; García-Sánchez, Mordán, \& Prado-Lorenzo, 2012; García-Sánchez, Mordán, \& Cuadrado-Ballesteros, 2014; Cuadrado-Ballesteros, Mordán, \& García-Sánchez, 2014; Bisogno \& Cuadrado-Ballesteros, 2017); these financial ratios come from the private sector and are calculated on the basis of financial and budgetary information. It is worth noting that they have been introduced in the public sector under the banner of new public management (NPM) (Guthrie, Olson, \& Humphrey, 1999; Broadbent \& Guthrie, 2008).

Table 1. Measuring the local financial condition

\begin{tabular}{|c|c|c|}
\hline Indicators & Definition & $\begin{array}{l}\text { Relation to financial } \\
\text { condition }\end{array}$ \\
\hline Cash solvency & $\begin{array}{l}\text { - Cash Surplus Index (CSI): difference between short-term } \\
\text { receivables, liquidity and net short-term liabilities }\end{array}$ & + \\
\hline \multicolumn{3}{|l|}{ Budgetary solvency: } \\
\hline Sustainability & $\begin{array}{l}\text { - Non-Financial Budgetary Results Index (NFBRI): current } \\
\text { budgetary payables, nonfinancial capital budgetary payables } \\
\text { divided by nonfinancial current budgetary receivables, } \\
\text { nonfinancial capital budgetary receivables } \\
\text { - Adjusted income: Income for the financial year by } \\
\text { applying IPSAS minus extraordinary revenues plus } \\
\text { extraordinary expenses. } \\
\text { - Net debt: Total liabilities minus financial assets. }\end{array}$ & - \\
\hline \multirow[t]{2}{*}{ Flexibility } & $\begin{array}{l}\text { - Net Saving Index (NSI): Net saving divided by current net } \\
\text { settled claims }\end{array}$ & + \\
\hline & $\begin{array}{l}\text { - Financial Charge Index (FCII): Annual amortization } \\
\text { payment minus interest and principal per inhabitant } \\
\text { - Net Debt Index (NDI): Addition of the net change of } \\
\text { financial assets divided by the number of inhabitants }\end{array}$ & - \\
\hline \multirow[t]{2}{*}{ Vulnerability } & $\begin{array}{l}\text { - Current Financial Independence Index (CFII): Current } \\
\text { budgetary payables divided by current budgetary receivables } \\
\text { except current grants. }\end{array}$ & - \\
\hline & $\begin{array}{l}\text {-Total Financial Independence Index (FII): Budgetary } \\
\text { payables divided by budgetary receivables except grants. } \\
\text { - Fiscal Revenue Index (FRI): Fiscal receivables divided by } \\
\text { net current budgetary receivables }\end{array}$ & + \\
\hline Service level solvency & $\begin{array}{l}\text { - Current Expenditure Index (CEI): Current budgetary } \\
\text { payables per inhabitant. }\end{array}$ & + \\
\hline
\end{tabular}

Source: (Cuadrado - Ballestreros et al., 2016).

Moreover, in recent years, the worldwide financial crisis has led financial sustainability to become a relevant concept in public entities which is even more important than the other three features, particularly in local governments within a context with a reduction of public revenues followed by public expenditure cuts (Bailey, Valkama, \& Salonen 2014; Checherita-Westphal, Hallett, \& Rother 2014; IMF 2014; Pérez-López, Plata-Díaz, Zafra-Gómez, \& López-Hernández, 2013).

In this context, international authorities have highlighted the need for sustainable strategies to be developed to create the necessary conditions to achieve financial health as well as ensure intergenerational equity (Cabaleiro, et al., 2013).

European Union fiscal sustainability reports (European Union, 2012; European Union, 2015) refer to financial sustainability as the ability of an entity to continue current public policies and public services delivery without changing the taxation and indebtedness levels. In a wider definition, sustainability refers to solvency in terms of inter-temporal budget constraints, considering the ability to meet costs now and in the future through revenues. 
Moreover, the International Public Sector Accounting Standards Board (IPSASB) has recently published a recommended practice guideline entitled "Reporting on the Long-Term Sustainability of an Entity's Finances", which provides recommendations linked to the concept of governmental solvency in terms of inter-temporal budget constraints (IPSASB, 2013).

In summary, financial sustainability links public services delivery with the current level of taxation and debt limits; more specifically, if an entity can cover the requests for public services without increasing taxes or using debt, it will be considered a sustainable entity; conversely, if it needs to increase taxes or the level of indebtedness to deliver the current services, it will be considered an unsustainable entity.

This document defines three inter-related dimensions of long-term fiscal sustainability summarized in table 1: revenue, debt and service. For each dimension, the IPSASB highlights two aspects: the capacity of the entity to manage the dimension and the level of dependency (vulnerability) of the external factors that the entity itself cannot control (Bisogno, Cuadrado-Ballesteros, \& García-Sánchez, 2017).

Table 2. Financial sustainability dimensions

\begin{tabular}{|c|c|c|c|}
\hline Dimension & Definition & Capacity & Vulnerability \\
\hline Service & $\begin{array}{l}\text { Public services that the entity } \\
\text { can deliver in terms of quantity } \\
\text { and quality given the current } \\
\text { level of taxation and debt } \\
\text { limits. }\end{array}$ & $\begin{array}{l}\text { To maintain or increase the } \\
\text { quantity and/or quality of } \\
\text { public services. }\end{array}$ & $\begin{array}{l}\text { To external factors that are detrimental to } \\
\text { the capacity to maintain or increase the } \\
\text { quantity and/or quality of public services } \\
\text { (e.g., if the level of public services is } \\
\text { determined by other levels of } \\
\text { government). }\end{array}$ \\
\hline Revenue & $\begin{array}{l}\text { Taxation levels given debt } \\
\text { limits and policy intentions in } \\
\text { terms of public services } \\
\text { delivery. }\end{array}$ & $\begin{array}{l}\text { To maintain or increase } \\
\text { taxation levels or introduce } \\
\text { new revenue sources. }\end{array}$ & $\begin{array}{l}\text { To willingness of taxpayers to accept the } \\
\text { taxation levels and dependence of } \\
\text { external sources. }\end{array}$ \\
\hline Debt & $\begin{array}{l}\text { Debt levels given taxation } \\
\text { levels and policy intentions in } \\
\text { terms of public services } \\
\text { delivery. }\end{array}$ & $\begin{array}{l}\text { To meet financial } \\
\text { commitments or increase } \\
\text { debt. }\end{array}$ & $\begin{array}{l}\text { To market confidence and interest rate } \\
\text { risk. }\end{array}$ \\
\hline
\end{tabular}

Source: Bisogno et al. 2017.

Accordingly, in order to define the financial sustainability in local governments, scholars tend in general to take into account some core elements, including:

- Public services delivery. The local government pursues the sustainability if it has the ability to maintain or increase social welfare. A reduction in the quality/quantity of the public services provided by local governments that could affect the citizens' wellbeing, since the most important welfare needs are usually related to the public services (Cuadrado-Ballesteros et al. 2014).

- Cost-efficiency. Sustainability defines the optimum relation between the public services delivery and its cost so as to be cost-efficient (Lohri, Camenzind, \& Zurbrügg, 2014) -i.e. the ability to provide the best public services in terms of quantity and quality with the lowest level of taxation.

- Debt. The governments, with the aim of being efficient, provide the best public services with the lowest level of taxation could accumulate debt indefinitely. There could even be situations where the debt and interest would be paid by issuing a new debt (European Union, 2015). Therefore, sustainability does not only refer to the revenues-expenses trade-off, but also to the level of indebtedness as a means of financing.

- Intergenerational equity. Sustainability requires the respect of equity over time; in particular, it must not compromise the ability of future generations to meet their needs (Dollery \& Grant 2011). A sustainable entity can manage public finances now by ensuring that future generations of taxpayers will not face the financial consequences of services provided to the current generation.

After discussing the context and methodological approach, the next sections discuss in detail the aspects about the case of Rome, the largest Italian municipality, which have experienced a situation of crisis and where a plan to restore a good financial condition has been implemented. The final section defines the conclusion. 


\section{Setting the Context}

Italian Local Governments (ILGs) act simultaneously at different levels: by setting the local regulatory framework and providing institutional services to citizens (e.g. civil registry), by delivering public services either directly (namely social services) or through private organizations (with specific regard to public utilities (e.g. ACEA, AMA) in which they often hold shares (Manes Rossi, 2011).

Over the last two decades, the degree of organizational and financial autonomy enjoyed by ILGs has significantly increased. Focusing on the financial changes, starting from the 2001 Constitutional reform, Italian institutional arrangements have gradually moved towards a decentralized model where municipalities are responsible for a wider range of activities and are finally entitled to raise taxes. However, they remain markedly dependent on transfers and grants from the Central Government, and, to a lesser extent, from the Regions, especially in low-income areas of the country (Anessi-Pessina, Sicilia \& Steccolini 2012; Mussari \& Giordano 2013).

The reduction of financial transfers from the other levels of governments is one of the main drivers of financial distress in ILGs, due to the slow implementation of reforms introducing a decentralized model and fostering ILGs' financial autonomy. It is worth highlighting that over the last years, Italian municipalities have suffered a dramatic reduction of transfers from the Central Government, decreasing from about 9.39 Euro billion/year in 2012 to 1.36 Euro billion/year in 2015 (Ministry of Treasury 2016 - data processed by IFEL). Moreover, as an effect of the last accounting reform (Legislative Decree 118/2011, as updated by Legislative Decree 126/2014 ), since 2015, ILGs are requested to depreciate revenues they are entitled to raise on a commitment basis but are unable to cash (L.D. 118/2011 - Attached 4/2 - Paragraph 3).

A further prominent issue to assess is the capacity of Italian budgeting and accounting systems to provide internal and external stakeholders with information suitable for indicating and monitoring ILGs financial health. Since 2015, ILGs are requested to approve a multi-year program budget (Legislative Decree 118/2011). Although the budget will not be an accrual budget (inasmuch it still relies both on commitment basis and cash basis), accrual accounting will be mandatory and, consequently, accrual financial reporting (Mussari, Tranfaglia, Reichard, Bjorna, Nakrosis, \& Bankauskaite, 2016).

The Italian legal framework regulating financial distress is within Legislative Decree 267/2000 (Consolidated Act for ILGs "Testo Unico per l'Ordinamento degli Enti Locali" hereafter TUEL). TUEL sets different degrees/layers of local governments' financial distress. The broadest refers to structurally distressed local governments (SDLGs): according to the TUEL (art 242), a LG is considered structurally distressed when there is evidence of severe and inconvertible conditions of disequilibrium, relying on a 10 parameters table (set every three-year by the Ministry of the Interior) to be attached to the annual financial report. When more than 5 out of the 10 parameters are out of requested ceilings, ILGs, under the control by the Ministry of the Interior, are forbidden to hire new personnel and are requested to raise fees in order to ensure the coverage of a specific percentage for both the general (namely, water and waste) and non-general (nursery, parking, etc.) services.

Therefore, municipalities are considered as structurally in deficit (art. 242) when more than half of the following parameters are out of the acceptable ranges:

1. the amount of annual financial deficit is higher than $5 \%$ of the operating revenues;

2. the amount of the revenues (Titles I and III of the Financial Budget only) from the current year, but still to be received, is higher than $42 \%$ of the operating revenues;

3. the amount of revenues (Titles I and III of the Financial Budget only) due in past accounting periods, but still to be received, is higher than $65 \%$ of the operating revenues from the current year;

4. the total amount of commitments from previous accounting periods, that are still unpaid, is higher than $40 \%$ of the operating expenses;

5. expenses due to the legal procedure of enforced judicial compensation is higher than $0.5 \%$ of the operating expenses;

6. the total amount of expenses for personnel is higher than $40 \%, 39 \%$ or $38 \%$ of the operating expenses (depending on municipality's size: the smaller the municipality, the higher the percentage);

7. the exposed capital debt is higher than $150 \%$ of the operating revenues $(120 \%$ in the case of financial deficit); unrefunded cash-advance (at the end of the fiscal year) is higher than $5 \%$ of the operating revenues;

8. off-balance debts occurred in the current year is higher than $1 \%$ of the operating revenues; 
9. unrefunded cash-advance (at the end of the fiscal year) is higher than $5 \%$ of the operating revenues;

10. budgetary re-balancing from the selling assets or affecting reserves is higher than $5 \%$ of the total operating expenses.

However, over the years structurally distress parameters resulted insufficient in forecasting financial distress (IFEL, 2016).

Within the wider conception of structurally distressed local governments, there are two different degrees/layers of local governments' financial distress: LGs in financial distress (TUEL - art. 244) and LGs which are committed to a plan to restore the financial equilibrium (TUEL - art. 243-bis).

The most severe condition of financial distress (FD), occurs when (TUEL - art. 244) either a local government cannot guarantee the performance of institutional functions and delivery of the essential services or it is no longer able to face the debts by resorting to ordinary means to restore the financial equilibrium (such as three-year redemption plans and mortgages).

In 2017, data from the Ministry of the Interior showed that there are 105 ILGs (2 provinces and 103 municipalities) facing financial distress. Most of the ILGs in financial distress are located in Southern Italy (94.28\%). Moreover, more than half of them are in two regions: Calabria (28 LGs in FD) and Campania (27 LGs in FD).

Table 3. Local governments in financial distress in Italy (data from the Ministry of the Interior)

\begin{tabular}{llllllllc}
\hline $\begin{array}{l}\text { Year } \\
\text { Area }\end{array}$ & 2011 & 2012 & 2013 & 2014 & 2015 & 2016 & 2017 & Total number of LGs in financial distress \\
\hline Northern Italy & - & 1 & - & 1 & - & - & - & 2 \\
Central Italy & - & 2 & - & 1 & - & 1 & - & 4 \\
Southern Italy & 3 & 11 & 20 & 19 & 19 & 6 & 21 & 99 \\
Total & $\mathbf{3}$ & $\mathbf{1 4}$ & $\mathbf{2 0}$ & $\mathbf{2 1}$ & $\mathbf{1 9}$ & $\mathbf{7}$ & $\mathbf{2 1}$ & $\mathbf{1 0 5}$ \\
\hline
\end{tabular}

Source: IFEL (2017) from data by the Ministry of the Interior on 25th May 2017.

Law 174/2012 has introduced a more flexible instrument to deal with financial distress: the multi-year re-balancing procedure (so called ante-financial distress - hereafter AFD). Accordingly, ILGs can be committed to a (up to) ten-year long plan (agreed with the Ministry of the Interior but to be approved by the Court of Auditors) in order to restore the financial equilibrium (TUEL - art. 243-bis). Differently from the financial distress regulated by art. 244, the AFD does not require a Special Commissioner Body responsible for the debts resulting from the past periods assessment and payment. ILGs in AFD can have access to a specific Rotative Fund aimed at improving the rebalancing, but they have to respect the expenditure constraints and ensure that the fees on the services they provide cover the services costs according to the specific percentages set out by the Law (TUEL - art. 243-bis, catch 9).

In May 2017, there were 173 ILGs committed to a plan to restore the financial equilibrium (Table 4). Most ILGs in AFD (114) are located in Southern Italy, with the remaining 34.10\% being divided among the Northern (30 ILGs) and Central Regions (29 ILGs).

Table 4. Italian Local governments committed to a plan to restore the financial equilibrium

\begin{tabular}{lccccccc}
\hline Year & 2012 & 2013 & 2014 & 2015 & 2016 & 2017 & Total number of LGs in financial distress \\
Area & & & & & & & 30 \\
\hline Northern Italy & 1 & 8 & 8 & 6 & 1 & 6 & 29 \\
Central Italy & 1 & 12 & 3 & 2 & 5 & 6 & 114 \\
Southern Italy & 23 & 28 & 22 & 17 & 9 & 15 & $\mathbf{1 7 3}$ \\
$\quad$ Total & $\mathbf{2 5}$ & $\mathbf{4 8}$ & $\mathbf{3 3}$ & $\mathbf{2 5}$ & $\mathbf{1 5}$ & $\mathbf{1 7}$ & \\
\hline
\end{tabular}

Source: IFEL (2017) from data by the Ministry of the Interior on 25th May 2017.

\section{Research Method}

From a methodological point of view, the paper is based on a case study, which offers the opportunity to 
understand what happens instead of what ought to happen (Scapens, 1990) in a specific context.

The aim of the following case study is to explain the reasons for management practices in a large municipality in a condition of financial distress in order to understand what is the way for pursuing financial health. Scholars have been debating approaches to analyse contents of financial sustainability. Our analysis has taken into account the peculiarities of financial plans imposed by the specific legislation for Rome as the capital of Italy. It represents an explanatory case study, where the focus of the research is on the specific case of the municipality of Rome and where the theory is used in order to understand and explain the specific, rather than to produce generalizations.

In detail, the focus has been to understand the processes that occur inside the "black box" of the organizational, institutional and strategic implementation of the reorganization practices and routines (Parker, 2014) of the municipality of Rome. The explanation of this case study has been a process of discovering the necessary critical points to be explained.

In this case study, these steps have been followed:

a) Preparation. After reviewing the available theories which were considered relevant to the case, a checklist of things to look for in the study (printing Italian Laws on ILGs and Law-Decrees for Rome and downloading other documents from official web sites) has been developed;

b) Collecting and assessing evidence. The preparatory review of theory has given an initial indication of the types of evidence which should be looked for in the case study (collecting financial reports of municipality of Rome across years 2007-2016);

c) Identifying and explaining patterns. Various themes and patterns have emerged. Models (diagrams, tables, etc.) which attempt to link the various themes and issues (financial sustainability dimensions, Italian local governments in financial distress and pre-distress, evolution of structurally distress parameters for Rome from 2007 to 2016, etc.) have been prepared. The analysis has been developed taking into account the two areas of management in the Municipality of Rome after the Law Decree n. 112/2008: the extraordinary management of the Special Commissioner (for past debts emerged not later than April 28th 2008) and the ordinary management (for debts emerged after April 28th 2008);

d) Report and conclusions. The report of the analysis is presented in paragraph 5 to make the case and its explanations intelligible and plausible to readers, with the conclusions in paragraph 6 which suggests also possible directions for future research.

With specific regards to step a), it started from the Legislative Decree 267/2000 (Consolidated Act for ILGs, henceforth TUEL) in order to outline the institutional framework. It is worth highlighting that TUEL consists, inter alia, of a specific section ruling LGs in financial distress. The overview of the Italian public financial management system relies both on TUEL as well as Legislative Decree 118/2011 introducing the so-called accounting harmonization. The ad-hoc discipline on the City of Rome has been approached in this framework, in order to point out any similarities and differences between the Italian Capital and other Italian municipalities in financial distress. In order to supplement the case study with financial information, we resorted to and processed the financial data from official documents (namely The Special Commissioner's financial reports). In addition, we conducted informal interviews in order to clarify some technical aspects (that were not explained in official documents) with public accounting experts (as the councilor responsible for accounts of the Municipaly of Rome and one of the Italian researchers of the Financial Institute for LGs).

\section{Case Study: The Municipality of Rome}

The City of Rome is the capital of Italy and the home of the Italian government. With 2,870,336 residents in $1,285 \mathrm{~km} 2$, and 15 small administrative municipalities, it is also the country's largest and most populated town and fourth-most populous city in the European Union. It is the centre of the Metropolitan City of Rome, which has a population of 4.3 million residents. Rome is also the city where The Vatican City is located, an independent country geographically located within the city boundaries, the only existing example of a country within a city and for this reason, it has often been defined as the capital of two states.

The municipality of Rome presents a peculiar legislation experiencing important financial constraints but it is working effectively to regain full expenditure autonomy and lowering financial debts.

In order to collect and assessment the evidence, we evaluate the evolution of the distress parameters in the last ten years about the municipality. Therefore, we evaluate a set of parameters (amount of annual financial deficit; amount of revenues; total amount of commitments; expenses; exposed capital debt; off-balance debts; 
unrefunded cash-advance; budgetary re-balancing) to analyse the financial conditions. The municipality of Rome shows some evidence of serious troubles in terms of financial sustainability as showed in table 5 although it could not be considered structurally distressed according a various type of the parameters (set out by the Ministry of Interior on the basis of TUEL.

Table 5. City of Rome - Evolution of the structurally distress parameters from 2007 to 2016

\begin{tabular}{|c|c|c|c|c|c|c|c|c|c|c|c|}
\hline & Parameter/Indicator & 2007 & 2008 & 2009 & 2010 & 2011 & 2012 & 2013 & 2014 & 2015 & 2016 \\
\hline 1 & $\begin{array}{l}\text { Amount of annual financial } \\
\text { deficit higher than } 5 \% \text { of the } \\
\text { operating revenues }\end{array}$ & & & & & & & & & & \\
\hline 2 & $\begin{array}{l}\text { Amount of revenues (Titles I } \\
\text { and III of the Financial Budget } \\
\text { only) from the current year, but } \\
\text { not as yet received, higher than } \\
42 \% \text { of the operating revenues }\end{array}$ & $X$ & $X$ & & & & & $X$ & & & \\
\hline 3 & $\begin{array}{l}\text { Amount of revenues (Titles I } \\
\text { and III of the Financial Budget } \\
\text { only) due in past accounting } \\
\text { periods, but not as yet received } \\
\text { higher than } 65 \% \text { of the } \\
\text { operating revenues from the } \\
\text { current year }\end{array}$ & n.a. & n.a. & $X$ & $X$ & $\mathrm{X}$ & & & $\mathrm{X}$ & $X$ & $X$ \\
\hline 4 & $\begin{array}{l}\text { Total amount of commitments } \\
\text { from previous accounting } \\
\text { periods, that are still unpaid, } \\
\text { higher than } 40 \% \text { of the } \\
\text { operating expenses }\end{array}$ & $X$ & $X$ & $X$ & $X$ & $X$ & $X$ & $X$ & $X$ & $X$ & $X$ \\
\hline 5 & $\begin{array}{l}\text { Expenses due to legal } \\
\text { procedure of enforced judicial } \\
\text { compensation are higher than } \\
0.5 \% \text { of the operating expenses }\end{array}$ & & & & & & & $X$ & $\mathrm{X}$ & $X$ & $X$ \\
\hline 6 & $\begin{array}{l}\text { Total amount of expenses for } \\
\text { personnel higher than } 38 \% \text { of } \\
\text { the operating expenses }\end{array}$ & & & & & & & & & & \\
\hline 7 & $\begin{array}{l}\text { Exposed capital debt higher } \\
\text { than } 150 \% \text { of the operating } \\
\text { revenues ( } 120 \% \text { in case of } \\
\text { financial deficit) }\end{array}$ & & & & & & & & & & \\
\hline 8 & $\begin{array}{l}\text { Off-balance debts occurred in } \\
\text { the current year higher than } 1 \% \\
\text { of the operating revenues }\end{array}$ & & & & & & & & & & \\
\hline 9 & $\begin{array}{l}\text { Unrefunded cash-advance (at } \\
\text { the end of the fiscal year) } \\
\text { higher than } 5 \% \text { of the operating } \\
\text { revenues }\end{array}$ & n.a. & n.a. & & & & & & & & \\
\hline 10 & $\begin{array}{l}\text { Budgetary re-balancing from } \\
\text { selling assets or affecting } \\
\text { reserves higher than } 5 \% \text { of the } \\
\text { total operating expenses }\end{array}$ & n.a. & n.a. & & & & & & & & \\
\hline \multicolumn{12}{|c|}{$X$ means that parameters are out of the acceptable ranges } \\
\hline
\end{tabular}

Source: Rome's Financial Statements (Years 2007-2016).

The most alarming indicator seems to be the amount of commitments from the previous accounting periods that are still unpaid: this parameter has been higher than $40 \%$ of the operating expenses for the whole period of 
analysis, highlighting the City difficulty to pay off its debts. However, there is more dangerous evidence: from 2009 to 2011 and in 2014-2015, the amount of revenues due in past accounting periods, but still not received ("residui attivi", henceforth RA) has been steadily high (more than $65 \%$ of the operating revenues from the current year revenues). It is worth pointing out that a large extent of the RA is a key indicator of the organizational incapacity to cash its credits, or, even worse, a signal of holding in the budget/financial report credits no longer due or difficult to collect, thus hiding a potential imbalance.

After a view of the current state, we move towards the third phase. We study the case in detail to identify what are institutional factor and the approaches implemented to exit of the state of crisis. The capacities of responses, the reactions are explained with two patterns: the rebalance of the debt and the cost-efficiency plan.

\subsection{Rebalancing the Debt}

Looking back to ten years ago, Rome collected over the years a huge amount of debts, about 22.5 Euro billion in 2008, that was transferred to the government along with some credits (nearly 5 Euro billion) in order to let the new mayor, from the centre-right party (the same party that was ruling the country in that period), to be in charge of the city, having full powers and no heavy burden like debt to deal with. However, Rome was not officially considered in financial distress thanks to an ad-hoc legislation: Law-Decree n. 112/2008 established a governmental Special Commissioner (appointed by the Central Government) to be responsible for the previous debt management as well as restoring the municipal financial equilibrium:

- On 30th September 2008, the deficit to be rebalanced was 9.571 Euro million, resulting from the difference between the municipal debt (12.797 Euro million) and the credits (3.226 Euro million);

- According to the second rebalancing plan of 30th July 2010, the total deficit - including interest and new off-balance debts - rose to 16.753 Euro million, resulting from the difference between the total debt $(22.454$ Euro million) and the credits (5.701 Euro million);

- Law-Decree n. 225/2010 entitled the Special Commissioner to update the rebalance plan issued in 2010 in case of new debt/credit related to the period ante 28th April, 2008.

In a certain way, the Italian Government recognized Rome the right not to fail due to its role as the Capital, giving the mayor time to evaluate exactly what the entire amount of debts inherited by the last administration was, thus creating a special administrative procedure to assess the debts discovered over time but originated before the 28th of April 2008, the date that was decided by the Parliament to freeze the financial situation and evaluate all the assets and liabilities of Rome.

The last Law-decree called "Salva Roma" in 2014 gave the Commissioner new resources to deal with the rising debt, that was increasing due to new amounts owed by the City of Rome involving off-balance payments recognized by the Courts or offices. After that, in April 2015, the former Commissioner issued the financial statement with all the amounts involved giving the Parliament a clear idea of the work done to manage the liabilities transferred from the city to this special means along with the recovery plan updated to that time.

The Commissioner operated with a strong mandate from the government that allowed the offices to settle special procedures to improve the effective transitions with the creditors and gain reductions of over $20 \%$ of the due amount. According to the TUEL art. 258, c.3, ILGs in financial distress are entitled to settle agreements with creditors reducing the amount due from $40 \%$ to $60 \%$. This normative prevision is consistent with the Special Commissioner's power to reduce the debts by a minimum of $20 \%$. It is worth pointing out that the credits managed by the Special Commissioner (as well as debts handled by the Extraordinary Commissioner appointed in the case of financial distress) cannot be subjected to foreclosures and without being compelled to time constraints.

In order to manage and pay off the huge debt transferred from the City of Rome to this new institution, the government provided the Special Commissioner with the resources needed by increasing the Personal Income tax rate, that had just been raised in the city of Rome, and by taking part of the fees from the air passenger duty and security charges. Therefore, the overall amount of resources available to pay off all the debts was financed with a $500 € /$ Mil annual payment for 40 years, partially covered by the Central government ( $300 € / \mathrm{Mil})$ and the Municipality of Rome (200 €/Mil). The Commissioner will remain in charge until the non-financial debt will be extinguished, this means that the quicker the creditors will be restored, the less it will cost the citizens for the activities carried out by the Special Commissioner. This is the main reason why the former commissioner decided to open two credit lines that gave enough cash to reduce the initial debt from $22.4 € / \mathrm{Bn}$ to $14.1 € / \mathrm{Bn}$ (2014). The main task of the Special Commissioner in 2010 was to start dealing with the non-financial debts, as shown in the graph below, i.e. $8,6 € / \mathrm{Bn}$ decreased significantly to nearly $3 € / \mathrm{Bn}$ (2015). 


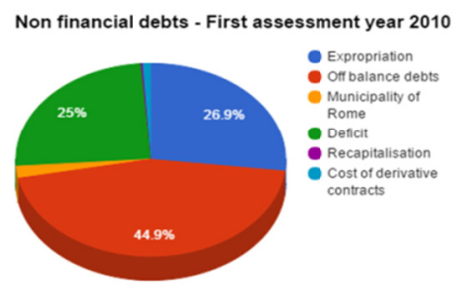

Figure 1. Non-financial debts

Source: Data processing from The Special Commissioner's Financial Report (2010).

The following table 6 provides a comprehensive overview of the current financial situation of the special commissioner's accounts to clearly understand how the recovery plan works and what the performances gained until now are.

Table 6. Trends of Commissioner's Debts and Credit flows $(€ / \mathrm{k})$

\begin{tabular}{lcccccccc}
\hline & $\begin{array}{c}\text { Balance } \\
\text { 2010/07 (*) }\end{array}$ & 2010 & 2011 & 2012 & 2013 & 2014 & 2015 & 2016 \\
\hline Non financial debts & 8.641 .511 & 6.665 .591 & 5.549 .820 & 4.199 .781 & 3.577 .736 & 3.328 .000 & 3.240 .338 & 3.152 .675 \\
Financial debts & 13.812 .175 & 13.467 .480 & 12.916 .797 & 11.912 .543 & 11.240 .000 & 10.731 .000 & 9.861 .246 & 8.991 .493 \\
$\begin{array}{l}\text { Principal amount } \\
\text { (A) }\end{array}$ & 7.123 .848 & 7.026 .973 & 6.793 .699 & 6.552 .369 & 6.226 .000 & 5.974 .000 & 5.495 .765 & 5.017 .529 \\
Interest amount (B) & 6.688 .327 & 6.440 .507 & 6.123 .098 & 5.360 .174 & 5.014 .000 & 4.757 .000 & 4.365 .482 & 3.973 .964 \\
Total debt (C) & 22.453 .686 & 20.133 .071 & 18.466 .617 & 16.112 .324 & 14.817 .736 & 14.059 .000 & 13.101 .584 & 12.144 .168 \\
Credit (D) & 5.700 .945 & 2.980 .856 & 2.726 .109 & 2.217 .739 & 1.944 .000 & 1.862 .000 & 1.845 .606 & 1.829 .212 \\
Deficit (E) & 16.752 .741 & 17.152 .214 & 15.740 .508 & 13.894 .585 & 12.873 .736 & 12.197 .000 & 11.255 .978 & 10.314 .956 \\
Net amount to & 10.064 .414 & 10.711 .708 & 9.617 .410 & 8.534 .411 & 7.859 .736 & 7.440 .000 & 6.890 .496 & 6.340 .992 \\
cover (C-D-B) & & & & & & & \\
$(*)$ According to L.D.225/2010 art.2,c.7 (reassessment of total Debts and Credits until April 28th 2008) & & & \\
\hline
\end{tabular}

Source: Data processed from Commissioner's financial report to Parliament (2010-2014).

The overall debts decreased by $51 \%$ from 2010 to 2016 , with an average of $8 \%$ per year. The Special Commissioner focused mainly on the non-financial debts, decreased by $82 \%$ in seven years, thanks to the special power given by the law authorizing unilateral reductions of court expenses and legal interests with the aim of quickly paying all the creditors that were interested in being paid immediately. However, the credits transferred to the Special Commissioner steadily decreased due to doubtful debts and recovered claims.

\subsection{The Cost-efficiency Plan}

Just before the first Commissioner finished his mandate, in 2013, the elections gave power to a new mayor that had to ask the government for further financial aid to cover (a large amount of new debts that were produced from 2008 to 2013); the government recognized Rome a 110 Euro/Mil new transfer as a sort of repayment for the extra-cost supported by Rome due to its special status as the Italian capital. In 2015, in order to obtain the final approval of Parliament, the mayor had to accept a strict cost-cutting plan with a $10 \%$ cut of structural expenditures over three years (2014-2016), having as the baseline the average of the previous five years (2009-2013). From 2014 onwards, the City of Rome had to face a severe cut-down program that involved structural costs and the right balance between savings and virtuous spending review programs. The decision of cost-cutting began by reducing consultancy, ICT costs, rents for offices, representation expenses and trips. Table 7 gives an idea of the macro category of all the expenses included in the rebalancing plan approved by the Italian government that allowed Rome to receive a further contribution of $110 € /$ Mil every year. 
Table 7. Rebalancing plan for the expenses categories

\begin{tabular}{lcc}
\hline \multicolumn{1}{c}{$\begin{array}{c}\text { Rebalancing plan Synthesis (main expenses } \\
\text { categories) }\end{array}$} & $\begin{array}{c}\text { Structural Historical Expenditures (2009-2013) } \\
\text { Average }\end{array}$ & $\begin{array}{c}\text { Expenditure Target (from 2016 } \\
\text { onwards) }\end{array}$ \\
\hline Public Service Contract & 1.581 .381 .657 & 1.375 .928 .860 \\
Purchases of goods and services & 1.775 .773 .397 & 1.447 .364 .499 \\
Social Service & 347.432 .792 & 326.244 .679 \\
School and preschool & 215.790 .836 & 208.071 .181 \\
Utilities & 205.619 .876 & 162.410 .365 \\
Rents & 126.545 .287 & 101.236 .230 \\
Minor expenditures & 221.760 .827 & 185.232 .579 \\
Off-balance-sheet liabilities & 70.000 .000 & - \\
Other service contracts & 189.765 .820 & 156.171 .824 \\
Other goods and services & 398.857 .959 & 307.997 .641 \\
Cost of personnel & 1.061 .566 .279 & 1.004 .285 .742 \\
Borrowing costs & 40.000 .000 & 40.000 .000 \\
Other & & 153.550 .803 \\
Total structural current expenditure & 4.458 .721 .333 & 4.021 .129 .904 \\
\hline
\end{tabular}

Source: Rebalancing plan of Roma Capitale, 2014.

The rebalancing plan of Roma Capitale (2014 - 2016) suggests that the Central Government has clearly focused on expenditure constraints in order to help Rome overcome the financial distress. As shown in Table 6, the city of Rome was committed to dealing with sharp reductions of the current expenditures (by 437,6 Euro million/year) in order to meet the Government - a set target of 4,021 Euro million from 2016 onwards. The most affected categories were utilities $(-21 \%)$, rents $(-20 \%)$ and purchases of goods and services $(-18.5 \%)$, However the reduction in economic activity and the corresponding increases in unemployment and social welfare needs (Paulais, 2009) reduced the commitments on social services $(-6.1 \%)$.

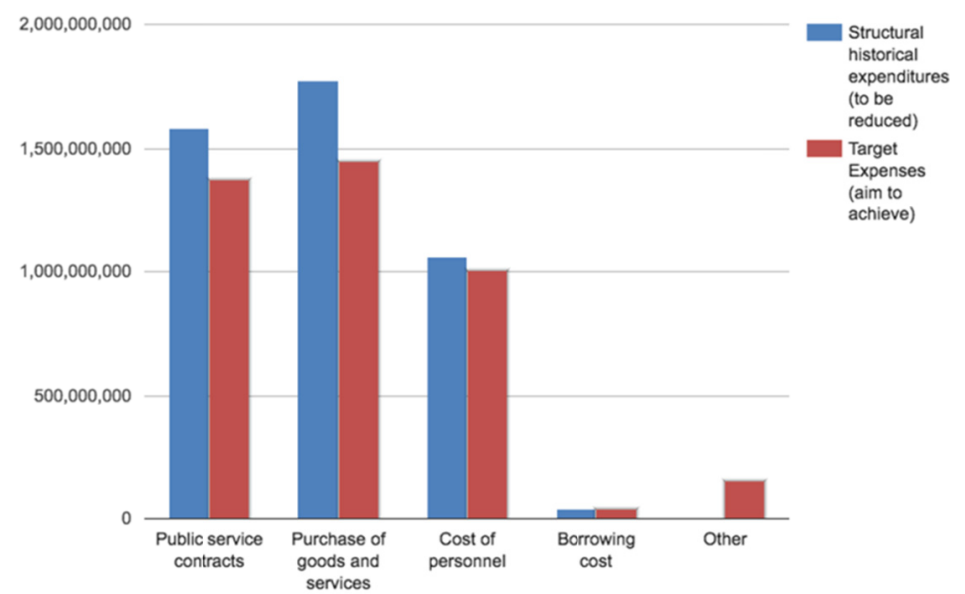

Figure 2. Reduction trends of city expenses, main categories

Source: Rebalancing plan of Roma Capitale, 2014.

This trend was also supported by a more detailed analysis of the expenditures made in the past years by providing a parameter for each spending category calculated as an average of the expenses made in the past five years (2009-2013), reduced by using a specific coefficient in order to achieve a more than $400 € /$ mil decrease of the structural expenses over three years (2014-2016).

\section{Conclusions and Directions for Future Research}

In the recent time, the context of austerity and crisis in the local governments has focused on looking for a solution to avoid the distress while improving their financial health (Barbera et al., 2017). Therefore, a system to monitor the financial situation of local authorities is needed in order to understand what the governments' proceeding to manage the crisis are. The combination of capacities and reactions, (i.e. management of slack 
resources, income generation, developing anticipatory capacity) is a good example of how to deal with financial difficulties.

Consequently, to understand how financial crisis can have impact on different variables, the starting point of this paper was an analysis of the current literature on how to define a good financial condition for ILGs considering how to restore a good condition for the ILGs that are in a situation of financial distress (with it not being necessary that they are declared in a condition of "financial distress").

In order to identify a good financial condition for ILGs, we have taken into account mainly some measures of budgetary solvency (such as sustainability, flexibility and vulnerability indicators) and three inter-related dimensions of long-term fiscal sustainability summarized: revenues (taxes), debts and cost of services.

We have remarked that the high degree of organizational and financial autonomy experienced by ILGs over the last two decades has gradually changed the management model of public resources. Italian municipalities have seen their autonomy increase as well as their responsibility for a wider range of activities; they are entitled to raise taxes but they still remain significantly dependent on transfers and grants from the Central Government (and, to a lesser extent, from the Regions). In the last five years, this "mixed approach" has been confirmed (by Law) with the multi-year re-balancing procedure AFD in order to allow ILGs to restore the financial equilibrium through access to a specific "rotative fund", while also respecting expenditure constraints and covering services costs with their fees.

From a methodological point of view, we analyse the data with a qualitative approach. In particular, we focus on a single case study through an explanatory case study following four prescribed steps (Scapens, 1990): preparation (the choice of the case to analyse), collecting and assessing evidence, identifying and explaining patterns, report and conclusions evaluating the analysis retrospectively of the change process over 10 years. We analysed the municipality of Rome because it has been selected due to evidence of serious troubles in terms of financial sustainability and its efforts in planning to lower the financial debts notwithstanding Rome not being considered structurally distressed according to the parameters set out by the Italian Ministry of Interior on the basis of the TUEL (art. 242).

The fact that the Italian Government recognized Rome the right not to fail due to it being the Italian capital has determined that the municipality was not officially considered in financial distress thanks to ad-hoc legislation (Law-Decree n. 112/2008) that established a governmental Special Commissioner to be responsible for restoring the municipal financial equilibrium, with large transfers from the Central Government across the years 2008-2013. The main task of the Special Commissioner was to start dealing with the "non-financial" debts, that have been significantly reduced across the years 2010-2015.

Regarding a specific set of indicators to measure public organizations' financial health (Greenberg \& Hiller 1995; CICA 1997; Nollenberger et al., 2003), the analysis of the Municipality of Rome has shown that some indicators would suggest Rome's financial health while others not. In greater detail, Rome has never been able to generate enough liquidity to pay its short-term debts (short-term solvency). Nevertheless, its expenditures were higher than its revenues (ne budget solvency), so that in 2014 the City was committed to a recovery plan by setting expenditure ceilings. The appointing of a Special Commissioner in 2008, 2010 and 2013, with the delivering of extraordinary transfers aimed to avoid troubles in terms of long-term solvency, by improving the payment of long-term obligations incurred before April 2008. Finally, Rome has never been able to provide and sustain essential services to its citizens (service-level solvency).

However, according to a second set of indicators, the budgetary solvency (Greenberg \& Hiller, 1995; Zafra-Gómez et al., 2006; CICA 1997; CICA 2009) of Rome cannot be considered as fully satisfied. First, the level of financial sustainability (i.e. the capacity of an entity to promote and preserve the social wellbeing of the citizens through public policies and public services delivery) decreased over the last two decades (at least until 2014): the existing public services have been delivered and obligations have been covered by raising taxation levels and, to a lesser extent, by increasing indebtedness. However, Rome has demonstrated a good level of flexibility, being able to respond to financial troubles, within the limits of its fiscal abilities via modifications to tax rates, public debt or transfers, although the latter furtherly increased the level of dependence on external financing (high level of vulnerability).

In conclusion, the in-depth examination of the Special Commissioner's financial reports and of the financial statements has demonstrated that, in addition to the Central Government transfers, three main actions have been realized:

1) reduction of the total debts; 
2) reduction of the deficit;

3) cost-efficiency plan (with a 10\% reduction of the structural expenditures).

These actions have modified the level of budgetary solvency of the municipality of Rome, demonstrating not only the increased level of flexibility during the considered period of analysis, but also its high vulnerability.

It is probably too early to evaluate the complexity of these strategies on the financial sustainability because it would require supplementary information on the level of the existing services, evaluation of their quality and a focus on the level of revenues (taxes) after the restoring plan, that could be analyzed in a future step of this research.

However, considering that the politician could be interested in disclosing the performance in financial information in order achieve political goals (Guarini, 2016), the evaluation of the strategies to implement have the aim to pursuing not only the capacity for reaction to crises but above all, the development and the creation of new opportunities as active resilience (Steccolini et al., 2015).

We think that our work will contribute to the debate on both the theoretical and practical underpinnings to represent the financial conditions in local governments, that are focused on the specific measures for budgetary solvency: sustainability, flexibility, and vulnerability as measurement to restore financial health in a period of crisis.

\section{References}

Anessi-Pessina E., Sicilia M. F., \& Steccolini I. (2012). Budgeting and Rebudgeting in Local Governments:

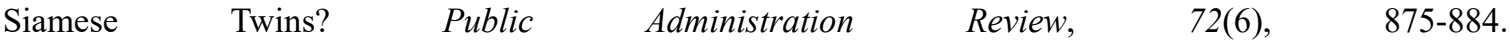
http://dx.doi.org/10.1111/j.1540-6210.2012.02590.x

Audit Commission. (2007). Use of Resources. Guidance for Councils, Audit Commission, London. https://www.croydon.gov.uk/sites/default/files/articles/downloads/resources.pdf

Bailey, S. J., Valkama, P., \& Salonen, S. (2014). The EU's public finance crisis: causes, consequences and cure. Public Money \& Management, 34(2), 83-90. http://dx.doi.org/10.1080/09540962.2014.887514

Barbera, C., Jones, M., Korac, S., Saliterer, I., \& Steccolini, I. (2017). Governmental financial resilience under austerity in Austria, England and Italy: How do local governments cope with financial shocks?. Public Administration, 95(3), 670-697. https://doi.org/10.1111/padm.12350

Berne, R. (1992). The Relationships Between Financial Reporting and the Measurement of Financial Condition. Research Report No. 18, GASB. Norwalk, CT.

Berne, R., \& Schramm, R. (Eds.) (1986). The Financial Analysis of Governments. NJ: Prentice Hall.

Bisogno M., Cuadrado-Ballesteros, B, \& García-Sánchez, I. M. (2017). Financial sustainability in local governments: definition, measurement and determinants, In Rodríguez Bolívar, Manuel Pedro (Eds.), Financial sustainability in public administrations. Exploring the Concept of Financial Health, (pp. 57-83). Palgrave Macmillan.

Bisogno, M., \& Cuadrado-Ballesteros, B. (2017). Explaining the relation between efficiency and financial condition: Empirical analysis on Italian local governments, In Rodríguez Bolívar, Manuel Pedro \& López Subires, María Deseada (Ed.), Financial Sustainability and Intergenerational Equity in Local Governments, (in press). IGI Global.

Bisogno, M., Citro, F., \& Tommasetti, A. (2014). The Financial Distress of Public Sector Entities: Evidence from Italian Public Universities. International Journal of Accounting, Auditing and Performance Evaluation, 10(2), 203-227. https://doi.org/10.1504/JJAAPE.2014.060221

Boyne, G. A. (1996). Constraints, Choice and Public Policies (1st ed.). London: JAI Press.

Cabaleiro, R., Buch, E., \& Vaamonde, A. (2013). Developing a method to assessing the municipal financial health. The American Review of Public Administration, 43(6), 729-751. https://doi.org/10.1177\%2F0275074012451523

Capalbo, E., \& Grossi, G. (2014), Assessing the influence of socioeconomic drivers on Italian municipal financial destabilization, Public Money \& Management, 34(2), 107-114. https://doi.org/10.1080/09540962.2014.887518

Carmeli, A. (2003), Introduction: fiscal and financial crises of local governments, International Journal of Public Administration, 26(13), 1423-1430. https://doi.org/10.1081/PAD-120024404 
Carmeli, A. (2008). The Fiscal Distress of Local Governments in Israel: Sources and Coping Strategies. Administration and Society, 39, 984-1007. https://doi.org/10.1177\%2F0095399707309358

Checherita-Westphal, C., Hughes Hallett, A., \& Rother, P. (2014). Fiscal sustainability using growth-maximizing debt targets. Applied Economics, 46(6), 638-647. http://dx.doi.org/10.1080/00036846.2013.861590

CICA. (1997). Indicators of Government Financial Condition. Canadian Institute of Chartered Accountants: Toronto.

CICA. (2009). Public Sector Statements of Recommended Practice (SORP) 4. Indicators of Financial Condition. Canadian Institute of Chartered Accountants: Toronto.

CIPFA, (2014). Risk, Resilience and Reform, CIPFA Annual Conference 2nd to 3rd July 2014, London

Coe C. K. (2008). Preventing local government fiscal crises: emerging best practices. Public Administration Review, 68(4), 759-767. http://dx.doi.org/10.1111/j.1540-6210.2008.00913.x

Cohen, S., Doumpos, M., Neofytou, E., \& Zopounidis, C. (2012). Assessing financial distress where bankruptcy is not an option: An alternative approach for local municipalities. European Journal of Operational Research, 218(1), 270-279. https://doi.org/10.1016/j.ejor.2011.10.021

Cuadrado-Ballesteros, B, Mardàn, N., \& Frías-Aceituno (2016). Transparency as a Determinant of Local Financial Condition, In Augusta da Conceição Santos Ferreira; Graça Maria do Carmo Azevedo; Jonas da Silva Oliveira \& Rui Pedro Figueiredo Marques (Eds.), Global Perspectives on Risk Management and Accounting in the Public Sector, (pp 202-225). IGI Global.

Cuadrado-Ballesteros, B., Mordán, N., \& García-Sánchez, I. M. (2014). Is Local Financial Health associated with Citizens' Quality of Life? Social Indicators Research, 119, 559-580. https://doi.org/10.1007/s11205-013-0533-2

Dollery, B., Crase, L., \& Byrnes, J. (2006). Local government failure: why does Australian local government experience permanent financial austerity? Australian Journal of Political Science, 41(3), 339-353. http://dx.doi.org/10.1080/10361140600848952

Dollery, B., \& Grant, B. (2011). Financial Sustainability and Financial Viability in Australian Local Governments. Public Finance and Management, 11(1), 28-47.

European Union. (2012). Fiscal Sustainability Report. European Commission: Brussels.

European Union. (2015). Fiscal Sustainability Report. European Commission: Brussels

GASB. (1987). Concepts Statement $N^{o} 1$ of Governmental Accounting Standards Board: Objectives of Financial Reporting. Governmental Accounting Standards Board: Norwalk.

García-Sánchez, I. M., Mordán, N., \& Prado-Lorenzo, J. M. (2012). Effect of the Political System on Local Financial Condition: Empirical Evidence for Spain's largest Municipalities. Public Budgeting and Finance, 32(2), 40-68. https://doi.org/10.1111/j.1540-5850.2011.00986.x

García-Sánchez, I. M., Mordán, N., \& Cuadrado-Ballesteros, B. (2014). Do Electoral Cycles affect Local Financial Health? Policy Studies, 35(6), 533-556. https://doi.org/10.1080/01442872.2014.971727

Greenberg J., \& Hiller, D. (1995) Indicators of financial condition for governments. Paper presented at the 5th Conference of Comparative International Governmental Accounting Research, Paris-Amy. Retrieved from http://www.iceis.org/iceis2005/abstracts_2005.htm

Groves, M., Godsey, W., \& Shulman, M. (1981). Financial indicators for local government. Public Budgeting \& Finance, 1(2), 5-19. http://dx.doi.org/10.1111/1540-5850.00511

Guarini, E. (2016). The day after: newly-elected politicians and the use of accounting information. Public Money \& Management, 36(7), 499-506. https://doi.org/10.1080/09540962.2016.1237135

Hendrick, R. (2004). Assessing and measuring the fiscal heath of local governments: Focus on Chicago suburban municipalities. Urban Affairs Review, 40(1), 78-114. https://doi.org/10.1177/1078087404268076

Honadle, B.W. (2003). The states' role in U.S. local government fiscal crises: a theoretical model and results of a national survey. International Journal of Public Administration, 26(13), 1431-1472. http://dx.doi.org/10.1081/PAD-120024405

IFEL (2016). Il bilancio 2016. Le nuove regole finanziarie, Studi e Ricerche http://www.fondazioneifel.it/documenti-e-pubblicazioni/item/8506-il-bilancio-2016 
IMF (International Monetary Fund) (2014). Vertical Fiscal Imbalances and the Accumulation of Government Debt. No.14/209. Washington, DC: IMF.

Inman, R. P. (1995). How to have a fiscal crisis: Lessons from Philadelphia. American Economic Review, 85(2), 378-383

IPSASB. (2013). Reporting on the Long-term Sustainability of an Entity's Finances. International Public Sector Accounting Standards Board: New York.

Jones, S., \& Walker, R. G. (2007). Explanators of Local Government Distress. Abacus, 43(3), 396-418. http://dx.doi.org/10.1111/j.1467-6281.2007.00238.x

Kloha, P., Weissert, C. S., \& Kleine, R. (2005). Developing and testing a composite model to predict local fiscal distress. Public Administration Review, 65(3), 313-323. http://dx.doi.org/10.1111/j.1540-6210.2005.00456.x

Lohri, C. R., Camenzind, E. J., \& Zurbrügg, C. (2014). Financial Sustainability in Municipal Solid Waste Management: Costs and Revenues in Bahir Dar, Ethiopia. Waste Management, 34, 542-552. https://doi.org/10.1016/j.wasman.2013.10.014

Lopez-Hernández, A. M., Zafra-Gómez, J. L., \& Ortíz-Rodríguez, D. (2012). Effects of the Crisis in Spanish Municipalities' Financial Condition: An Empirical Evidence (2005-2008). International Journal of Critical Accounting, 4(5/6), 631-645. https://doi.org/10.1504/IJCA.2012.051457

Manes Rossi, F. (2011). Analysis of Solvency in Italian Local Governments: The Impact of Basel III, the ICFAI journal of financial risk management. http://dx.doi.org/10.2139/ssrn.1830520

Mussari, R., \& Giordano, F. (2013). Emerging Issues in Italian Fiscal Federalism: The Case of Municipalities, in Denita Cepiku-David K. Jesuit-Ian Roberge (Eds.), Making Multilevel Public Management Work: Stories of Success and Failure from Europe and North America, CRC Press, pp. 27-50.

Mussari, R., Tranfaglia, A. E., Reichard, C., Bjorna, H., Nakrosis, V., \& Bankauskaite, S. (2016). Design, Trajectories of Reform, and Implementation of Performance Budgeting in Local Governments: A Comparative Study of Germany, Italy, Lithuania, and Norway, in Sabine Kuhlmann and Geert Bouckaert (Eds.), Local Public Sector Reforms in Times of Crisis, Palgrave Macmillan UK, pp. 101-119

National Audit Office. (2013). Financial Sustainability of Local Authorities 2013 [The Comptroller and Auditor General], HC 888 Session 2013/14 30 January 2013, London: The Stationery Office

Nollenberger, K., Groves, S. M., \& Valente, M. G. (Eds.). (2003). Evaluating Financial Condition: A Handbook for Local Government. Washington, DC: IC/CMA.

Pagano, M., \& Moore, R. J. T. (Eds.) (1985). Cities and fiscal choices: a new model of urban public investment. Duke University Press.

Parker, L. (2014). Qualitative perspectives: Through a methodological lens. Qualitative Research in Accounting \& Management, 11(1), 13-28. https://doi.org/10.1108/QRAM-02-2014-0013

Paulais, T. (2009). Local Governments and the Financial Crisis: An Analysis (1st eds.). Washington, DC, The Cities Alliance,

PARK, K. (2004), To file or not to file: the causes of municipal bankruptcy in the united states. Journal of public budgeting, accounting \& financial management, 16(2), 228-256.

Pérez-López, G., Plata-Díaz, A. M., Zafra-Gómez, J. L., \& López-Hernández, A. M. (2013). Deuda viva municipal en un contexto de crisis económica: análisis de los factores determinantes y de las formas de gestión. Revista de Contabilidad-Spanish Accounting Review, 16(2), 83-93. https://doi.org/10.1016/j.rcsar.2012.12.001

Petersen, J. E. (1977). Simplification and standardization of State and Local Government fiscal indicators. National Tax Journal, 30(3), 299-311.

Raphael, D., Renwick, R., Brown, I., \& Rootman, I. (2010). Quality of life indicators and health. In D. Raphael (Ed.), Health promotion and quality of life in Canada. Toronto: Canadian Scholars' Press.

Scapens, R. W. (1990). Researching Management Accounting Practice: The role of case study methods. British Accounting Review, 22, 259-281. https://doi.org/10.1016/0890-8389(90)90008-6

Steccolini, I., Barbera, C., \& Jones, M. (2015). Governmental financial resilience under austerity: The case of English local authorities. CIMA Executive Summary Report, 11(3), 1-13. 
Zafra-Gómez, J. L., López-Hernández, A. M., \& Hernández-Bastida, A. (2006). Evaluación de la condición financiera de las administraciones locales a través del análisis de componentes principales. Presupuesto y Gasto Público, 43, 113-126.

Zafra-Gómez, J. L., López-Hernández, A. M., \& Hernández-Bastida, A. (2009). Evaluating Financial Performance in Local Government: Maximizing the Benchmarking Value. International Review of Administrative Science, 75(1), 151-167. https://doi.org/10.1177\%2F0020852308099510

\section{Notes}

Note 1. It is worth recalling that the parameters are set every three years by the Ministry of Interior. The parameters have been steadily revised in 2009 (from 8 parameters set in 2006-2008 to 10 parameters requested in 2009-2011 and 2012-2014). During the period 2006-2008, some parameters had different ceilings (see specific notes on the table), while parameters n.3, n.9, and n. 10 were not checked. Moreover, the ILGs were asked to maintain total interests on mortgages under $12 \%$ of the current revenues (Title I to III of the Financial Budget).

\section{Copyrights}

Copyright for this article is retained by the author(s), with first publication rights granted to the journal.

This is an open-access article distributed under the terms and conditions of the Creative Commons Attribution license (http://creativecommons.org/licenses/by/4.0/). 